\title{
Analisis Kesesuaian Materi pada Buku Teks Matematika Kelas VII dengan Kurikulum 2013
}

\author{
Apolonia Hendrice Ramda \\ STKIP St. Paulus Ruteng. Jalan Ahmad Yani No. 10, Ruteng, Flores, Nusa Tenggara Timur, Indonesia \\ Email: apoloniahendrice@gmail.com
}

Received: 20 May 2017; Revised:7 June 2017; Accepted: 10 June 2017

\begin{abstract}
Abstrak
Tujuan penelitian ini adalah mendeskripsikan kesesuaian buku teks matematika kelas VII edisi revisi 2014 dengan Kurikulum 2013 dilihat dari standar isi, standar proses, dan standar penilaian. Penelitian ini merupakan penelitian kualitatif dengan menggunakan analisis konten. Teknik analisis data dilakukan dengan tahap pendefinisian unit, penentuan sampel, pencatatan, pereduksi data, penarikan kesimpulan, dan penarasian. Hasil penelitian menunjukkan bahwa kesesuaian materi dalam buku dengan Standar Isi pada Kurikulum 2013 dilihat dari (1) cakupan materi adalah sebesar 90,91\%. Pada cakupan materi dalam buku, tidak terdapat pokok bahasan Bidang Cartesius. (2) Kesesuaian KD adalah sebesar 95,45\%. (3) Keluasan materi adalah sebesar 90,91\%. (4) Kedalaman materi adalah sebesar 90,91\%. (5) Keakuratan materi adalah sebesar 81,82\%. (6) penyajian materi adalah sebesar 87,27\%. Kesesuaian materi dalam buku dengan Standar Proses pada Kurikulum 2013 dilihat dari substansinya adalah sebesar 90,9\%. Kesesuaian materi dalam buku dengan Standar Penilaian pada Kurikulum 2013 adalah sebesar 54,55\%.
\end{abstract}

Kata Kunci: buku teks matematika, materi, standar isi, standar proses, standar penilaian, kurikulum 2013

\section{An Analysis of Relevance Between Mathematics Textbook Content for Seventh Grade and Curriculum 2013}

\begin{abstract}
This study aimed to describe the relevance of the materials in the 2014 revised edition mathematics textbook for Grade VII published by Puskurbuk to Curriculum 2013 in terms of the Content Standar, the Process Standar, and the Assessment Standar. This research was a qualitative study using content analysis. The data were analyzed by means of the instruments that had been validated. The data analysis was carried out through the stages of unit definition, recording, data reduction, conclusion drawing, and narration. The results of the study showed that the relevance of the materials in the book to the Content Standar in Curriculum 2013 is as follows. (1) In terms of the materials coverage, the relevance is $90.91 \%$. (2) In terms of Basic Competencies (BC) in Curriculum 2013 , it is $95.45 \%$. (3) In terms of the materials breadth, it is $90.91 \%$. (4) In terms of the materials depth it is $90.91 \%$. (5) In terms of the materials accuracy, it is $81.82 \%$. (6) In terms of the materials presenting, it is $87.27 \%$. The relevance of the materials in the book to the process standar in Curriculum 2013 in terms of the substance is $90.9 \%$. The relevance of the materials in the book to the Assessment Standard in Curruculum 2013 is 54.55\%.
\end{abstract}

Keywords: mathematics textbook, content, content standar, process standar, assessment standar, curriculum 2013

How to Cite: Ramda, A. (2017). Analisis kesesuaian materi buku teks Kemendikbud matematika kelas VII dengan Kurikulum 2013.PYTHAGORAS: Jurnal Pendidikan Matematika, 12(1), 12-22. doi:http://dx.doi.org/10.21831/pg.v12i1.14057

Permalink/DOI: http://dx.doi.org/10.21831/pg.v12i1.14057 


\section{PENDAHULUAN}

Inovasi dalam dunia pendidikan merupakan hal pokok yang perlu dilakukan sebagai upaya untuk mewujudkan tujuan pendidikan nasional. Dalam rangka mewujudkan tujuan pendidikan nasional tersebut, pemerintah Republik Indonesia melalui Kementerian Pendidikan dan Kebudayaan telah melakukan inovasi berupa evaluasi dan pembaharuan kurikulum. Hal tersebut ditandai dengan pemberlakuan kurikulum 2013 (K-13) pada tahun 2013. Seiring dengan pemberlakukan K-13, pemerintah menetapkan standar kompetensi lulusan (SKL) sebagaimana tercantum dalam Permendikbud nomor 54 tahun 2013 tentang Standar Kompetensi Kelulusan Pendidikan Dasar dan Menengah. Selain itu, sebagai acuan dalam merencanakan, melaksanakan dan menilai, maka ditetapkan pula standar isi, standar proses dan standar penilaian.

Penetapan standar isi, proses, maupun standar penilaian dalam implementasi K-13 tersebut diperlukan agar tercipta pembelajaran yang efektif dan efisien. Pembelajaran yang efektif dan efisien dapat membantu siswa mengembangkan sikap, pengetahuan, sekaligus keterampilannya. Proses pembelajaran yang efektif dan efisien juga didukung dengan sumber belajar yang baik. Salah satu sumber belajar yang dapat menunjang terciptanya pembelajaran yang efektif dan efisien tersebut adalah buku teks pelajaran (Mendikbud, 2013).

Buku teks pelajaran memiliki kaitan yang erat kaitannya kurikulum (Mesa \& Griffiths, 2012; Macintyre \& Hamilton, 2010). Selain itu, buku teks pelajaran merupakan salah kebutuhan utama dalam pembelajaran (Mesa \& Griffiths, 2012; Weinberg \& Wiesner, 2011) dan merupakan media yang menjadi elemen kunci untuk meningkatkan keefektifan dalam pembelajaran (Macintyre \& Hamilton, 2010). Dalam pelajaran matematika, buku teks pelajaran dapat membantu peserta didik dalam membangun pemahamannya terhadap matematika dan merepresentasikan matematika tersebut (Weinberg \& Wiesner, 2011; Shield \& Dole, 2012). Oleh karena itu, Buku teks pelajaran matematika hendaknya mendukung pencapaian kompetensikompetensi yang harus dikuasai oleh peserta didik sesuai dengan tingkat kelasnya.

Sebagai penunjang proses pembelajaran yang efektif dan efisien, buku teks pelajaran hendaknya memenuhi standar penilaian buku yang layak. Menurut Badan Standar Nasional
Pendidikan (BSNP), penilaian terhadap buku teks pelajaran mencakup 4 aspek yaitu materi, penyajian, bahasa dan grafika. Keempat aspek tersebut dapat menunjang kelayakan buku teks pelajaran yang dapat digunakan sebagai alat penunjang pembelajaran yang efektif dan efisien.

Salah satu aspek penting dalam buku teks pelajaran yang telah disebutkan yaitu materi, merupakan aspek yang secara langsung berpengaruh terhadap pengetahuan siswa. Pengetahuan siswa tersebut berkaitan dengan pengetahuan faktual, konseptual dan prosedural (Anderson \& Krathwohl, 2001). Oleh karena itu materi dalam buku teks pelajaran merupakan hal penting yang perlu diperhatikan. Hal yang diperhatikan dalam buku teks tersebut antara lain struktur buku maupun presentasi materinya (O'Keeffe, 2013). Begitu pula halnya dengan materi yang disajikan dalam buku teks matematika hendaknya menjadi salah satu saran bagi siswa untuk belajar, sehingga meningkatkan kognitif dan pengetahuan siswa.

Buku teks pelajaran yang mengacu pada Kurikulum 2013 hendaknya memenuhi Standar pendidikan yang sesuai dengan ketentuan dalam penerapan Kurikulum 2013. Ketentuan tersebut sebagaimana tercantum dalam standar isi, standar proses, maupun standar penilaian. Selain itu, buku teks pelajaran sebagai sarana yang mendukung pembelajaran yang efektif dan efisien, juga mendukung dilakukannya penilaian terhadap pencapaian peserta didik. Hal ini dapat dilakukan dengan pemberian soal-soal latihan, ulangan, pemberian tugas baik individu maupun kelompok, dan sebagainya. Penilaian dalam buku teks pelajaran yang mengacu pada kurikulum tertentu harus sesuai dengan Standar penilaian yang telah ditetapkan dalam Kurikulum yang digunakan tersebut. Begitu pula halnya dengan buku teks pelajaran yang mengacu pada Kurikulum 2013, penilaian dalam buku tersebut harus sesuai dengan kriteria penilaian dalam Kurikulum 2013.

Berdasarkan data yang diperoleh dari Dinas Pendidikan Kota Yogyakarta, terdapat 29 Sekolah Menengah Pertama (SMP) yang menggunakan Kurikulum 2013 pada tahun 2013, 56 SMP pada tahun 2014, dan 7 SMP pada tahun 2015-2016. Ketujuh SMP tersebut terdiri dari SMP Negeri 8, SMP Negeri 15, SMP Negeri 5, SMP Muh. 2, SMP IT Abubakar, Pangudi Luhur, dan Pembangunan Ma'arif. Dari survei awal yang dilakukan pada lima dari tujuh SMP yang menggunakan Kurikulum 2013 di kota 
Yogyakarta, yaitu SMP Negeri 8, SMP Negeri 15, SMP Negeri 5, Pangudi Luhur, dan Pembangunan Ma'arif, diperoleh hasil persentase banyaknya siswa (dari total 438 siswa) yang menggunakan buku teks dari beberapa penerbit buku teks matematika, yang dapat dilihat pada Tabel 1.

Tabel 1 Persentase Penggunaan Buku Matematka SMP Kurikulum 2013

\begin{tabular}{lc}
\hline \multicolumn{1}{c}{ Penerbit } & Persentasi Penggunaan \\
\hline Kemendikbud & $100 \%$ \\
Erlangga & $32,19 \%$ \\
Yudhistira & $1,83 \%$ \\
Yrama Widya & $0 \%$ \\
\hline
\end{tabular}

Dari data yang disajikan pada Tabel 1, diperoleh informasi bahwa buku teks pelajaran matematika yang digunakan oleh semua siswa adalah buku yang diterbitkan Kemendikbud yang dikenal dengan buku siswa, sedangkan penggunaan buku terbitan lainnya merupakan kejadian khusus. Meskipun buku guru dan buku siswa yang direkomendasikan oleh pemerintah dalam implementasi K-13 tersebut adalah buku yang telah ditelaah dan diterbitkan oleh pemerintah, namun tidak sedikit, bahkan seringkali mendapatkan kritisi dari berbagai pihak. Beberapa hasil penelitian terdahulu bahkan mengkomparasikan efektivitas penggunaan buku yang diterbitkan oleh pemerintah dengan buku yang dikembangkan sendiri oleh peneliti untuk suatu materi ajar tertentu. Hasil tersebut antara lain seperti yang diperoleh (Soeyono, 2014, p. 2016) yang mengungkap bahwa penggunaan bahan ajar yang dikembangkan olehnya justru lebih efektif dalam meningkatkan kemampuan berpikir kreatif dan berpikir kritis siswa. Penelitian yang dilakukan oleh Rusindrayanti \& Santoso (2015) tentang implementasi K-13 juga memberikan hasil yang serupa, yakni banyak guru yang kesulitan dalam melaksanakan pembelajaran. Salah satu faktor tersebut antara lain adanya sejumlah kesalahan dalam buku-buku yang digunakan (Rusindrayanti \& Santoso, 2015, pp. 93-94). Uraian tersebut memberikan bukti bahwa kualitas buku teks yang digunakan merupakan salah satu faktor yang mempengaruhi efektif tidaknya suatu pembelajaran.

Sehubungan dengan penggunaan buku teks yang diterbitkan oleh Kemendikbud tersebut, peneliti telah melakukan telaah singkat terhadap buku teks matematika SMP/MTS edisi revisi 2014 untuk kelas VII. Hasilnya menunjukkan bahwa pokok bahasan Bidang Kartesius tidak tercantum dalam uraian materi pada buku.
Padahal pokok bahasan tersebut termasuk dalam cakupan materi pada silabus SMP kelas VII yang tercantum dalam Permendikbud nomor 58 tahun 2014. Ketidaksesuaian ini berkaitan dengan Standar Isi dalam Kurikulum 2013. Hal ini didukung pula dengan hasil wawancara singkat yang dilakukan peneliti dengan guru matematika pada beberapa SMP yang menggunakan Kurikulum 2013 di Kota Yogyakarta, mengungkapkan bahwa siswa sulit memahami buku teks pelajaran matematika Kurikulum 2013 yang dikenal dengan buku siswa, karena penyajian materinya yang rumit baik dari konsep maupun contoh-contoh soal yang ditampilkan. Hal ini menyebabkan proses pembelajaran di kelas kurang berjalan lancar. Lebih lanjut diungkapkan bahwa beberapa soal tersebut tidak sesuai dengan kognitif siswa kelas VII. Karena itu, guru masih menggunakan beberapa soal dari buku teks matematika lainnya yang sesuai dengan tingkat kemampuan siswa kelas VII. Uraian mengenai fakta-fakta tersebut menunjukkan adanya indikasi bahwa buku teks matematika SMP/MTS edisi revisi 2014 untuk kelas VII belum sepenuhnya sesuai dengan Standar Isi Kurikulum 2013.

Beberapa penelitian berkaitan dengan analisis buku menunjukkan bahwa buku teks pelajaran masih perlu ditingkatkan kelayakannya. Penelitian yang dilakukan oleh Agustina (2015) memberikan hasil bahwa terdapat kekurangtelitian berupa kesalahan penomoran $\mathrm{KD}$ dan ketidaksesuaian KD yang tercantum dengan Permendikbud nomor 67 tahun 2013. Muatan Scientific Approach terpenuhi, muatan Authentic Assessment sudah memenuhi sebagian besar indikator namun perlu dilengkapi dengan rubrik penilaian.

Penelitian yang dilakukan oleh Sunday (2014) terkait dengan analisis terhadap 11 buku teks matematika oleh 117 guru matematika yang tersebar di 36 Sekolah Menengah Southwestern Nigeria, memberikan hasil bahwa buku-buku yang digunakan tersebut relevan, layak, dan mampu meningkatkan hasil belajar siswa, namun buku-buku tersebut masih perlu dilengkapi dengan Students' Workbook, panduan guru, latihan soal yang menantang dan warna-warna yang atraktif.

Penelitian yang dilakukan oleh Novianto \& Mustadi (2015) terhadap pemenuhan muatan tematik integratif, scientific approach, dan authentic assessment yang terdapat pada buku teks tematik terpadu Kurikulum 2013 dengan tema Bermain di Lingkunganku, memberikan 
hasil bahwa terdapat kesalahan penomoran KD dan ketidaksesuian materi dengan KD yang tercantum, muatan scientific approach tepenuhi, dan pada muatan authentic assessment belum dilengkapi dengan rubrik penilaian kemampuan siswa baik sikap, pengetahun dan keterampilan.

Penelitian yang dilakukan oleh Shield \& Dole (2012) memberikan hasil bahwa lima buku teks pelajaran matematika tingkat SMP yang beredar di Australia belum sepenuhnya dapat diandalkan untuk membantu siswa dalam penalaran belajar matematika secara mendalam. Siswa masih kesulitan dalam memahami isi buku teks pelajaran matematika, diantaranya karena penggunaan simbol dan bahasa yang sulit dipahami.

Kenyataan tersebut menunjukkan bahwa bahwa buku teks pelajaran yang digunakan dalam proses belajar mengajar masih perlu diperhatikan kelayakannya untuk digunakan dalam proses pembelajaran. Hal ini penting mengingat buku teks pelajaran merupakan sumber belajar penunjang pembelajaran yang merupakan implementasi kurikulum yang digunakan. Oleh karena itu, karena itu peneliti tertarik untuk menganalisis lebih lanjut mengenai kesesuaian materi pada buku teks Kemendikbud Matematika kelas VII edisi revisi 2014 dengan Kurikulum 2013, baik dari pemenuhan Standar isi, Standar Proses, maupun Standar Penilaian.

\section{METODE}

Penelitian ini merupakan penelitian kualitatif dengan menggunakan teknik content analisys. Pengumpulan data dilakukan pada bulan Maret sampai Mei 2016. Sumber data penelitian berasal dari buku teks pelajaran matematika kelas VII edisi revisi 2014 yang dikeluarkan secara resmi oleh pemerintah melalui Pusat Kurikulum dan Perbukuan (Puskurbuk). Buku teks pelajaran matematika tersebut adalah buku siswa dengan judul "Matematika", semester I dan II. Pemilihan buku berdasarkan hasil survei awal bahwa buku siswa tersebut merupakan buku yang paling banyak digunakan dan merupakan buku wajib, khususnya bagi SMP yang menggunakan Kurikulum 2013.

Pengumpulan data dalam penelitian ini dilakukan dengan pengamatan dan pencatatan terhadap aspek materi yang terdapat dalam buku siswa Kemendikbud Matematika kelas VII edisi revisi 2014 mengenai kesesuaiannya dengan Kurikulum 2013 dilihat dari kesesuaiannya dengan Standar Isi, Standar Proses, dan Standar
Penilaian. Pada penelitian ini analisis dimulai dengan melakukan telaah materi pada buku baik dari Standar Isi, Standar Proses, maupun Standar Penilaian, kemudian menyesuaikannya dengan rincian materi dalam Kurikulum 2013. Setelah itu dilakukan pencatatan dan deskripsi terhadap materi buku. Pencatatan dilakukan pada setiap bab yang terdapat dalam buku. Hasil analisis untuk setiap kategori dinyatakan dalam bentuk skor. Skor tersebut digunakan untuk menunjukkan seberapa besar kesesuaian materi buku dengan Kurikulum 2013.

Instrumen utama dalam penelitian ini adalah peneliti sendiri dengan menggunakan kriteria kesesuaian materi dalam buku dengan Standar Isi, Standar Proses, dan Standar Penilaian dalam Kurikulum 2013. Dalam melakukan penilaian terhadap kesesuaian buku dengan Kurikulum 2013, peneliti dibantu oleh seorang guru matematika SMP yang berpengalaman di bidangnya. Peran guru tersebut dapat membantu memberikan hasil penelitian yang mencerminkan keadaan sebenarnya.

Instrumen pengumpulan data yang digunakan dalam penelitian ini daftar cek yang berisi kriteria kesesuaian materi buku dengan Kurikulum 2013 yang disusun berdasarkan kajian referensi yang sebelumnya disetujui oleh para ahli (validator). Dalam membuat kriteria penilaian tersebut dimulai dengan mengumpulkan referensi pendukung yaitu Permendikbud pada Kurikulum 2013 yang berkaitan dengan Standar Isi, Standar Proses, dan Standar Penilaian. Kesesuaian materi dengan Standar Isi berkaitan dengan cakupan, keluasan, kedalaman, keakuratan, penyajian materi, dan kesesuaian KD. Kesesuaian materi dengan Standar Proses berkaitan dengan cara penyampaian materi, yaitu menggunakan pendekatan saintifik. Sedangkan kesesuaian materi dengan Standar Penilaian berkaitan dengan kriteria penilaian yang sesuai dengan Kurikulum 2013.

Pada penelitian ini, validitas dibuktikan dengan face validity dan content validity. Face validity dalam content analysis berarti menganalisis sesuatu yang masuk akal, dapat diterima dan dipercaya mengenai isi dari suatu teks. Sedangkan content validity meliputi keseluruhan pendefinisian konsep yang digunakan untuk mengukur. Selain menggunakan face validity dan content validity, untuk menunjukkan/ membuktikan validitas digunakan pula validitas semantic yaitu tingkatan yang menunjukkan kategori-kategori analitik bersesuaian dengan makna-makna pada teks atau aturan yang 
dipakai dalam konteks tertentu (Krippendorff, 2004, p. 323). Keakuratan mendeskripsikan makna yang terkandung pada teks merupakan hal penting dalam melakukan analisis konten.

Selain itu, reliabilitas instrumen ditentukan oleh reproducibility dan stability. Reliabilitas reproducibility terpenuhi apabila diperoleh hasil yang sama antara analisis peneliti dengan guru. Stability dalam content analysis adalah tingkatan yang mana hasil penelitian tidak berubah dari waktu ke waktu. Stability pada penelitian ini dicapai dengan cara membaca, mengkategorikan, dan menganalisis buku siswa teks matematika kelas VII edisi revisi 2014 dari aspek materi secara berulang-ulang sehingga diperoleh hasil yang sama.

Teknis analisis data dalam penelitian ini sesuai dengan tahap-tahap analisis yang dikemukakan oleh Krippendorf (2004, p.83), yang terdiri dari unitizing, recording, reducing, dan inferring. Tahap pertama adalah unitizing atau pendefinisian unit. Pada tahap ini ditentukan unit yang ingin diteliti, yaitu kesesuaian materi buku teks matematika dengan Kurikulum 2013 dilihat dari Standar sisi, Standar Proses, dan Standar Penilaian. Tahap Kedua yaitu, recording (perekaman/ pencatatan). Perekaman/ pencatatan dilakukan oleh peneliti dan dibantu oleh guru matematika. Analisis dimulai dengan melakukan telaah materi pada buku baik dari Standar Isi, Standar Proses, maupun Standar Penilaian, kemudian menyesuaikannya dengan rincian materi dalam Kurikulum 2013. Pencatatan dilakukan pada setiap bab yang terdapat dalam buku baik pada semester I maupun Semester II. Hasil analisis untuk setiap kategori yang dinyatakan dalam bentuk skor digunakan untuk menunjukkan seberapa besar kesesuaian materi buku dengan Kurikulum 2013. Persentase kesesuaian materi pada setiap kategori untuk standar isi, standar proses, dan standar penilaian ditentukan dengan rumus:

$$
\frac{\text { jumlah skor yang diperoleh }}{\text { jumlah skor maksimal }} \times 100 \% \text {; }
$$

Selanjutnya adalah tahap ketiga, Reducing (reduksi) dilakukan dengan menghilangkan halhal yang tidak relevan dengan penelitian. Penelitian ini khusus membahas aspek kesesuaian materi pada buku teks Kemendikbud Matematika kelas VII semester I dan II dengan Kurikulum 2013 dilihat dari Standar Isi, Standar Proses, dan Standar Penilaian. Pada penelitian ini hal-hal yang tidak berkaitan dengan aspek materi tidak dibahas. Keempat, Inferring (pena- rikan kesimpulan). Tahap ini dilakukan dengan menganalisis data untuk mencari makna dari unit-unit yang ada. Konteks yang ada diinferensi dengan konstruksi analitis. Konstruksi analitis adalah representasi dengan melakukan pemetaan terhadap hasil reduksi untuk memperoleh jawaban atas pertanyaan yang dapat disimpulkan dari hasil analisis. Pemetaan hasil analisis pada penelitian ini berdasarkan kriteria kesesuaian materi buku teks Kemendikbud Matematika kelas VII edisi revisi 2014 dengan Kurikulum 2013. 5) Narrating (menarasikan). Tahap ini dilakukan dengan menarasikan hasil analisis yang merupakan jawaban dari pertanyaan penelitian. Hasil/ kesimpulan terhadap kesesuaian materi buku teks pelajaran matematika kelas VII edisi revisi 2014 dengan Kurikulum 2013 yang dianalisis tersebut dideskripsikan secara umum.

\section{HASIL DAN PEMBAHASAN}

\section{Hasil}

Setelah dilakukan analisis kesesuaian buku dengan Standar isi, Standar Proses, dan Standar Penilaian, hasil tingkat kesesuaian materi dalam buku dengan Kurikulum 2013 dapat dilihat pada Tabel 2.

Berdasarkan Tabel 2, skor maksimal untuk cakupan materi adalah 1, skor maksimal untuk KD ditentukan berdasarkan banyaknya KD yang harus dipenuhi pada setiap pokok bahasan, sedangkan untuk keluasan, kedalaman, keakuratan, penyajian materi, kesesuaian langkah-langkah saintifik dan penilaian skor maksimalnya adalah 5. Total skor maksimal untuk cakupan materi adalah $11, \mathrm{KD}$ adalah 22 , sedangkan untuk keluasan, kedalaman, keakuratan, penyajian materi, kesesuaian langkahlangkah saintifik dan penilaian adalah 55. Skor 55 ini diperoleh dengan mengalikan skor maksimal pada masing-masing kategori, yaitu 5 dengan 11, yang merupakan banyaknya pokok bahasan untuk kelas VII. Dari Tabel 2 tampak bahwa kesesuaian materi dalam buku dengan materi dalam kurikulum 2013 dilihat dari cakupan materi adalah sebesar $90,91 \%$, KD sebesar $95,455 \%$, keluasan materi sebesar 90,91\%, kedalaman materi sebesar $90,91 \%$, keakuratan materi sebesar $81,82 \%$, kesesuaian dengan langkah-langkah saintifik sebesar 90,91\%, dan penilaian sebesar $54,54 \%$. Untuk lebih jelasnya berikut ini akan diuraikan lebih lanjut mengenai kesesuaian materi dalam buku dengan Kurikulum 2013. Penjelasan mengenai temuan 
Pythagoras, 12 (1), 2017 - 17

Apolonia Hendrice Ramda

dalam buku teks matematika kelas VII edisi revisi 2014 akan diuraikan pada subbab berikut.

Tabel 2. Rangkuman Hasil Analisis Kesesuaian Materi dalam Buku dengan Kurikulum 2013

\begin{tabular}{|c|c|c|c|c|c|c|c|}
\hline \multicolumn{6}{|c|}{ Standar Isi } & \multirow{2}{*}{$\begin{array}{c}\begin{array}{c}\text { Standar } \\
\text { Proses }\end{array} \\
\text { Langkah } \\
\text { Saintifik } \\
\end{array}$} & \multirow{2}{*}{$\begin{array}{c}\begin{array}{c}\text { Standar } \\
\text { Penilaian }\end{array} \\
\text { Penilaian }\end{array}$} \\
\hline Cakupan Materi & KD & $\begin{array}{c}\text { Keluasan } \\
\text { Materi }\end{array}$ & $\begin{array}{c}\text { Kedalaman } \\
\text { Materi }\end{array}$ & $\begin{array}{c}\text { Keakuratan } \\
\text { Materi }\end{array}$ & $\begin{array}{l}\text { Penyajian } \\
\text { Materi }\end{array}$ & & \\
\hline 1. Bilangan & 3 & 5 & 5 & 4 & 5 & 5 & 3 \\
\hline 2. Himpunan & 1 & 5 & 5 & 4 & 5 & 5 & 3 \\
\hline $\begin{array}{l}\text { 3. Segi Empat dan } \\
\text { segitiga }\end{array}$ & 3 & 5 & 5 & 4 & 4 & 5 & 3 \\
\hline 4. Garis dan Sudut & 2 & 5 & 5 & 5 & 5 & 5 & 3 \\
\hline $\begin{array}{l}\text { 5. Perbandingan } \\
\text { dan Skala }\end{array}$ & 3 & 5 & 5 & 4 & 4 & 5 & 3 \\
\hline $\begin{array}{l}\text { 6. PLSV dan } \\
\text { PtLSV }\end{array}$ & 2 & 5 & 5 & 4 & 5 & 5 & 3 \\
\hline $\begin{array}{l}\text { 7. Aritmetika } \\
\text { Sosial }\end{array}$ & 1 & 5 & 5 & 5 & 5 & 5 & 3 \\
\hline $\begin{array}{l}\text { 8. Bidang } \\
\text { Kartesius }\end{array}$ & 0 & 0 & 0 & 0 & 0 & 0 & 0 \\
\hline 9. Transformasi & 2 & 5 & 5 & 5 & 5 & 5 & 3 \\
\hline 10. Statistika & 2 & 5 & 5 & 5 & 5 & 5 & 3 \\
\hline 11. Peluang & 2 & 5 & 5 & 5 & 5 & 5 & 3 \\
\hline Total & 21 & 50 & 50 & 45 & 48 & 50 & 30 \\
\hline $\begin{array}{l}\text { Kesesuaian dengan } \\
\text { K-13 }\end{array}$ & $95,45 \%$ & $90,91 \%$ & $90,91 \%$ & $81,82 \%$ & $87,27 \%$ & $90,91 \%$ & $54,54 \%$ \\
\hline
\end{tabular}

\section{Pembahasan}

Standar Isi

Dalam buku teks pelajaran, cakupan materi berkaitan dengan kelengkapan pokok bahasan yang dapat menunjang Kompetensi Inti dan Kompetensi Dasar pada setiap tingkat kelas. Cakupan materi yang dimaksud sesuai dengan yang terdapat dalam Permendikbud nomor 58 tahun 2014 tentang Kurikulum 2013 Sekolah Menengah Pertama/Madrasah Tsanawiyah. Hasil analisis materi, mengungkapkan bahwa terdapat salah satu pokok bahasan yang tercantum dalam cakupan materi dan silabus matematika untuk SMP kelas VII, yang tidak dibahas dalam buku. Pokok bahasan tersebut adalah Bidang Cartesius. Oleh karena itu, penilaian pada cakupan materi mencapai total skor 10 dengan persentase kesesuaian dengan Kurikulum 2013 sebesar 90,91\%.

Selain itu, hasil analisis mengungkapkan bahwa KD 3.7 yaitu mendeskripsikan lokasi benda dalam koordinat Cartesius tidak tercantum dalam buku. Oleh karena itu, hasil penilaian untuk kesesuaian KD mencapai total skor 21 dengan persentase kesesuaian dengan Kurikulum 2013 sebesar 95,45\%.

Setiap pokok bahasan yang terdapat dalam buku (kecuali Bidang Cartesius) yaitu Bilangan, Himpunan, Perbandingan dan Skala,
Garis dan Sudut, Segi Empat dan Segitiga, PLSV dan PtLSV, Aritmetika Sosial, Transformasi, Statistika, dan Peluang, telah sesuai dengan keluasan materi dalam Kurikulum 2013 untuk tingkat SMP. Sehingga untuk keluasan materi mencapai total skor 50 dengan persentase kesesuaian dengan Kurikulum 2013 sebesar $90,91 \%$.

Kedalaman materi pada suatu pokok bahasan berkaitan dengan muatan dimensi pengetahuan yang terdapat dalam pokok bahasan tersebut. Semua pokok bahasan yang terdapat dalam buku, yaitu Bilangan, Himpunan, Perbandingan dan Skala, Garis dan Sudut, Segi Empat dan Segitiga, PLSV dan PtLSV, Aritmetika Sosial, Transformasi, Statistika, dan Peluang, kedalaman materinya sampai pada kegiatan mencipta. Namun demikian, ada buku ditemukan ketidaksesuaian materi dengan tingkat kognitif siswa SMP, yaitu pada beberapa soal latihan, yang mana siswa diminta untuk melakukan pembuktian suatu bilangan bukan bilangan rasional.

Pada dasarnya, siswa perlu dilatih untuk menalar dan membuktikan sedini mungkin. Hal ini dinyatakan dalam NCTM (2000, p.56), yaitu "Reasoning and proof should be a consistent part of students' mathematical experience in prekindergarten through grade 12". Hal ini menegaskan bahwa menalar dan membuktikan perlu diperkenalkan kepada siswa. Menalar dan 
membuktikan dalam matematika bukanlah hal yang mudah untuk dilakukan. Karena itu harus disesuaikan dengan tingkat kemampuan siswa pada setiap tingkat kelasnya. Bila siswa terbiasa melakukannya siswa akan memahami bahwa matematika dapat menjawab berbagai permasalahan di lingkungan sekitar dengan masuk akal.

Kemampuan kognitif tingkat SMP belum sampai pada kategori kognitif extended-abstract, yang mana pada kategori ini peseta didik diperkenalkan pada analogi yang sesuai dengan prinsip abstrak, mampu membuat hipotesis, membuktikan hipotesis, dan dapat membuat kesimpulan dari hipotesis yang telah dibuktikan tersebut. Peserta didik tingkat SMP kelas VII (usia 12-13 tahun) berada pada kategori kognitif multistructural akhir menuju kategori relational awal (Collis \& Biggs, 1982), yang mana peserta didik telah mampu berpikir secara abstrak dan menarik hubungan diantara elemen atau materi yang dipelajari, namun masih dalam tingkat pemula. Oleh karena itu, pembuktian yang diperkenalkan pada tingkat SMP masih dalam tahap mudah yang disesuaikan dengan tingkat kognitifnya. Kedalaman materi dalam buku mencapai total skor 55, persentase kesesuaian buku dengan Kurikulum adalah 90,9\%.

Dalam buku ditemukan beberapa hal berkaitan dengan ketidakakuratan materi. Terdapat ketidakakuratan soal pada latihan 1.8 yang terdapat pada buku semester I halaman 85 , yaitu pada soal nomor 8 (Kemendikbud, 2014a, p.85).

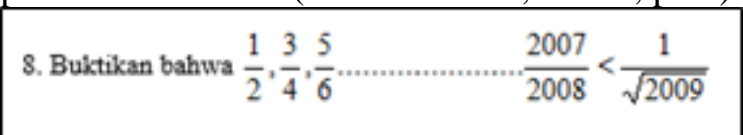

Gambar 1. Soal Latihan yang Tidak Akurat

Dari segi format, bentuk soal pada Gambar 1 belum menggambarkan maksud yang jelas dari penulis buku, apakah terjadi kesalahan pada penulisan atau memang penulis memiliki maksud tertentu. Belum dapat diketahui maksud dari penggunaan tanda baca koma (,) yang terdapat soal tersebut.

Terdapat ketidaksesuaian konsep tentang diagram Venn yang terdapat dalam buku pada halaman 110. Pada buku ditunjukkan bahwa diagram Venn digunakan untuk menyatakan anggota dari suatu himpunan. Hal ini tidak sesuai dengan konsep diagram Venn. Seharusnya diagram Venn digunakan untuk menyatakan hubungan dari beberapa himpunan, bukan hanya dari satu himpunan saja.
Pada pokok bahasan Perbandingan dan Skala yang terdapat pada halaman 178 ditemukan perbedaan pemahaman terhadap perbandingan dua besaran atau lebih. Contoh situasi yang terdapat pada kegiatan 3.2 menunjukkan bahwa perbandingan dapat dilakukan pada dua besaran yang berbeda. Hal ini bertentangan dengan konsep perbandingan. Perbandingan hanya dapat dilakukan pada besaran-besaran yang sama atau sejenis. Misalkan besaran panjang hanya dapat dibandingkan dengan besaran panjang. Besaran panjang tidak dapat disbandingkan dengan besaran luas, karena dua besaran tersebut tidak sama. Apabila satuan dari besaran sejenis yang dibandingkan berbeda, maka harus disamakan terlebih dahulu. Konsep perbandingan tidak dinyatakan secara jelas, sehingga terlihat bahwa perbandingan dapat dilakukan pada dua besaran yang berbeda. Contoh dan masalah yang ditampilkan pada kegiatan 3.2 tersebut merupakan laju (rate). Karena itu perlu diterangkan perbedaan antara laju, rasio, dan proporsi. Selain itu pada buku tidak diterangkan dengan jelas mengenai perbedaan antara perbandingan senilai dan perbandingan berbalik nilai. Padahal penyelesaian masalah pada kedua jenis perbandingan tersebut berbeda.

Pada pokok bahasan Segi Empat dan Segitiga terdapat kekeliruan pada konsep trapesium dan jajar genjang yang terdapat pada halaman 22 dan 23. Terdapat kata-kata "panjang alas" dan "sisi atas". Trapesium dan jajar genjang tidak memiliki sisi atas dan sisi alas, melainkan sepasang sisi yang sejajar. Selain itu, pengertian belah ketupat dan layang-layang mencampurkan sifat. Diagonal yang saling tegak lurus pada belah ketupat dan layang-layang merupakan sifat atau akibat dari pengertian, bukan termasuk dalam pengertian.

Pada pokok bahasan PLSV dan PtLSV terdapat kekeliruan pada pengertian variabel. Variabel biasanya mewakili kuantitas, bukan sembarang anggota suatu himpunan semesta. Selain itu, Pada latihan 2.2 yang terdapat dalam buku Kemendikbud matematika kelas VII semester II halaman 83, terdapat soal-soal operasi hitung bentuk aljabar, sedangkan materi bentuk aljabar baru diberikan di kelas VIII. Hal ini dapat menimbulkan kebingungan bagi siswa dalam mengerjakan soal-soal tersebut karena belum mendapat materi tentang bentuk aljabar.

Temuan tersebut menunjukkan bahwa masih terdapat ketidaksesuaian konten materi dalam buku dengan konsep matematika yang benar maupun tingkat kognitif siswa SMP kelas 
VII. Kedalaman materi dalam buku mencapai total skor 24, dengan persentasi kesesuaian dengan Kurikulum 2013 adalah 81,82\%.

Dari hasil analisis yang dilakukan, ditemukan bahwa untuk semua pokok bahasan kecuali pokok bahasan bidang kartesius, menyajikan peta konsep materi dan tujuan belajar yang jelas dan sesuai dengan Kompetensi Dasar pada setiap pokok bahasan.

Keterkaitan antar materi perlu diperhatikan. Materinya dihubungkan antara satu dengan yang lain agar siswa dapat memperoleh pemahaman yang mendalam terhadap materi yang disajikan. Hal tersebut sesuai dengan Permendikbud nomor 58 tahun 2014 yang menyebutkan bahwa materi dalam setiap pokok bahasan sebaiknya dikaitkan satu dengan yang lainnya (Mendikbud, 2014a). Begitu dengan pula dengan materi matematika sebaiknya dikaitkan dan diurutkan agar siswa mempunyai pemahaman yang mendalam terhadap materi yang dipelajari (NCTM, 2000). Materi prasyarat disajikan mendahului materi pokok yang berkaitan dengan materi prasyarat yang bersangkutan. Namun, pada buku tidak terdapat pokok bahasan bidang kartesius padahal pokok bahasan tersebut tercantum dalam silabus matematika kelas VII pada Permendikbud nomor 58 tahun 2014 dan materi prasyarat sebelum mempelajari materi transformasi.

Penyajian materi yang baik tidak menimbulkan kebingungan bagi pembaca. Penyajian uraian, contoh soal, gambar/ilustrasi, maupun latihan hendaknya disajikan dengan jelas, mudah dibaca, dan tidak berbelit-belit sehingga pembaca mudah memahami materi yang disajikan tersebut. Dalam buku ditemukan bahwa pada pokok bahasan segitiga dan segi empat, terdapat soal latihan yang disajikan secara bertele-tele yang mengandung informasi tidak penting.

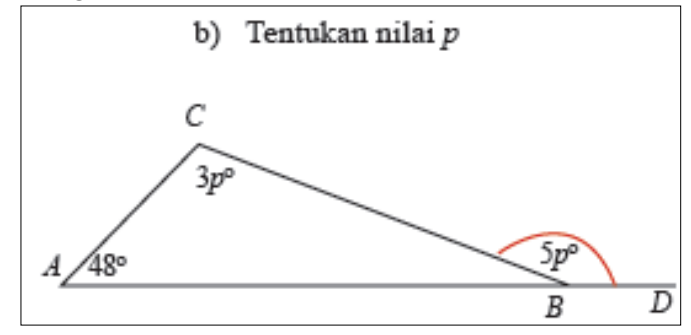

Gambar 2. Penyajian Soal yang Kurang Baik

Pemberian nama titik sudut A, B, C, dan D pada Gambar 2 tidak perlu dilakukan, karena pada soal yang diminta adalah menentukan nilai $p$. Bila pemberian nama titik sudut $\mathrm{A}, \mathrm{B}, \mathrm{C}$, dan
D tidak dicantumkan, tidak akan mengurangi informasi penting yang berkaitan dengan apa yang ditanyakan pada soal tersebut.

Selain itu pada pokok bahasan perbandingan dan skala tidak diuraikan secara jelas syarat untuk membandingkan dua besaran atau lebih sehingga contoh proporsi dan laju pada kegiatan 3.2 dianggap sama. Hal ini dapat menimbulkan pemahaman yang salah tentang syarat perbandingan. Selain itu, contoh masalah perbandingan senilai dan berbalik nilai tidak disajikan dengan jelas.

Keruntutan materi dalam buku telah disajikan dengan baik, uraian materi disajikan dari khusus ke umum yang sesuai dengan alur berpikir induktif. Selain itu uraian materi, contoh soal, dan latihan disajikan dari yang mudah ke sukar. Hal ini dapat membantu siswa dalam memahami materi yang disajikan, karena disesuaikan dengan tingkat berpikir siswa. Selain itu materi disajikan dari hal konkret yang dekat dengan siswa seperti mengaitkan dengan kehidupan sehari-hari ke hal-hal abstrak. Secara umum, keruntutan materi dalam buku telah disajikan dengan baik.

Penyajian materi yang baik juga didukung dengan materi yang dapat memotivasi siswa untuk belajar. Presentasi atau penyajian materi yang baik hendaknya dapat memotivasi siswa untuk mempelajari materi tersebut (Macintyre \& Hamilton, 2010). Lebih lanjut dijelaskan bahwa penggunaan visual dalam bentuk gambar dapat meningkatkan motivasi siswa untuk mempelajari atau bahkan sekedar membaca materi yang disajikan. Untuk memunculkan motivasi siswa dapat pula dengan mencantumkan penjelasan mengenai manfaat materi yang dipelajari. Hal ini sesuai dengan Permendikbud nomor 58 tahun 2014 yang menyatakan bahwa buku teks matematika sebagai sumber belajar juga berfungsi untuk meningkatkan motivasi belajar peserta didik. Motivasi belajar dapat didukung dengan penyajian yang menarik, menimbulkan rasa ingin tahu siswa, dan pengetahuan akan manfaat yang diperoleh atau pentingnya materi dalam buku teks tersebut. Materi yang memotivasi dapat pula ditandai dengan adanya penjelasan mengenai manfaat mempelajari materi yang disajikan dalam tiap bab (dapat pula berupa pengenalan terhadap tokoh-tokoh penemu konsep-konsep matematika). Selain itu, untuk menjelaskan materi sekaligus meningkatkan motivasi siswa dapat menggunakan gambar (bagan, diagram, ilustrasi, atau foto). 
Pada setiap pokok bahasan dalam buku terdapat pengenalan terhadap tokoh-tokoh yang berperan dalam ilmu matematika, gambargambar pendukung yang sesuai dengan materi yang dipelajari, serta adanya penjelasan mengenai manfaat mempelajari materi pada setiap pokok bahasan. Temuan tersebut menunjukkan bahwa penyajian materi dalam buku masih perlu diperbaiki lagi. Penyajian materi dalam buku mencapai total skor 48 , dengan persentase kesesuaiannya adalah $87,27 \%$.

Hasil yang diperoleh mengenai kesesuian buku teks matematika dengan standar isi kurikulum 2013 memberikan bukti empiris mengenai hal-hal yang menjadi penghambat implementasi kurikulum 2013. Hal tersebut sebagaimana yang dikemukakan oleh Rusindrayanti \& Santoso (2015, p.93) bahwa banyak guru yang kesulitan mengimplementasikan K13. Rusindrayanti \& Santoso (2015, p.94) menyebutkan bahwa pemerintah perlu memperhatikan kelayakan buku teks matematika yang digunakan dalam implementasi K13 karena masih terdapat banyak kesalahan di dalamnya. (Rusindrayanti \& Santoso, 2015, pp. 93-94)

\section{Standar Proses}

Hasil analisis mengenai kesesuaian buku teks matematika kelas VII edisi revisi tahun 2014 terhadap standar proses kurikulum 2013 menunjukkan bahwa seluruh pokok bahasan yang terdapat dalam buku tersebut, yaitu Bilangan, Himpunan, Perbandingan dan Skala, Garis dan Sudut, Segi empat dan Segitiga, PLSV dan PtLSV, Aritmetika Sosial, Transformasi, Statistika, dan peluang, telah menerapkan kegiatan pembelajaran dengan pendekatan saintifik dan dinyatakan secara eksplisit untuk setiap kegiatan pembelajarannya. Pada setiap kegiatan pembelajaran penyampaian materi baik itu pengenalan, pemahaman, maupun penerapan konsep dilakukan dengan kegiatan saintifik.

Hasil tersebut memberi bukti bahwa buku teks yang digunakan sesuai dengan standar proses yang telah ditetapkan oleh pemerintah. Pada Peraturan Pemerintah Nomor 32 Tahun 2013 dijelaskan bahwa pelaksanaan proses pembelajaran menggunakan pendekatan saintifik. Pedoman pelaksanaan pembelajaran dijelaskan lebih lanjut dalam Permendikbud nomor 103 tahun 2014 tentang Pembelajaran pada Pendidikan Dasar dan pendidikan Menengah yang salah satunya mendeskripsikan kegiatan pembelajaran dengan pendekatan saintifik yang meliputi lima pengalaman belajar, yaitu kegiatan mengamati (observing), menanya (questioning), mengumpulkan informasi/ mencoba (experimenting), mengasosiasi (associateing), dan mengomunkasikan (communicating) (Mendikbud, 2014b). Proses saintifik yang diterapkan dalam pembelajaran melatih siswa untuk belajar dengan cara ilmiah yaitu menggunakan prosedur-prosedur khusus dalam mempelajari suatu konsep. Hal ini sejalan dengan penjelasan yang diberikan oleh Gerde, Schacher, Wasik (2013, p.317) yang mengungkapkan bahwa metode saintifik merupakan suatu proses bertanya dan menjawab pertanyaan menggunakan prosedur khusus. Lebih lanjut, Gerde, Schacher, Wasik (2013) menjelaskan bahwa pembelajaran saintifik yang diterapkan dalam kelas membantu siswa secara efektif untuk membangun konsep ilmiah dan kemampuan dalam bahasa, literasi dan matematika.

\section{Standar Penilaian}

Hasil analisis mengenai kesesuaian buku teks matematika SMP kelas VII edisi revisi tahun 2014 menunjukkan bahwa masih ter dapat ketidaksesuaian penilaian dalam buku teks tersebut dengan standar penilaian kurikulum 2013. Secara keseluruhan penilaian yang dilakukan untuk setiap pokok bahasan yang terdapat dalam buku teks matematika SMP kelas VII edisi revisi 2014 terdiri dari pemberian tugas terstruktur, tes tertulis, dan proyek. Sementara itu, standar penilaian kurikulum 2013 sebagaimana yang disebutkan dalam Permendikbud nomor 104 tahun 2014 tentang Penilaian Hasil Belajar oleh Pendidik pada Pendidikan Dasar dan Pendidikan Menengah nomor yang menyebutkan bahwa penilaian dapat berupa tes tertulis, observasi terhadap diskusi, tanya jawab dan percakapan, serta penilaian terhadap tugas (untuk menilai kompetensi pengetahuan), atau menggunakan unjuk kerja/kinerja/praktik, proyek, produk, dan portofolio (untuk menilai kompetensi keterampilan).

Hasil analisis juga menunjukkan bahwa soal-soal yang terdapat pada latihan maupun uji kompetensi dalam setiap pokok bahasan tidak dilengkapi dengan kunci jawaban, sehingga soal-soal tersebut tidak dapat dipertanggungjawabkan baik dari konsep, prosedur, maupun hasilnya. Selain itu, tidak terdapat pemberian tugas mandiri tidak terstruktur. Padahal keberadaan tugas tidak terstruktur dapat membantu peserta didik untuk memahami materi yang dipelajari secara lebih mendalam. Setiap pokok bahasan yang terdapat dalam buku tidak 
dilengkapi dengan adanya tugas tidak terstruktur. Hal ini belum sepenuhnya menggambarkan penilaian yang sesuai dengan penilaian dalam Kurikulum 2013. Padahal, penilaian kurikulum 2013 menghendaki penilaian yang mencakup kemampuan-kemampuan yang kompleks. Hasil ini memiliki relevansi dengan hasil yang diperoleh Murdaningsih \& Murtiyasa (2016) yang menyebutkan soal-soal atau masalah-masalah yang digunakan dalam buku teks matematika kelas VIII masih belum sesuai dengan standar yang digunakan PISA. Dalam hal ini, soal-soal atau masalah yang disajikan

Yang Berdasarkan uraian mengenai kesesuaian buku teks matematika kelas VII edisi revisi tahun 2014 dengan standar isi, standar proses, dan standar penilaian pada kurikulum 2013, diperoleh gambaran bahwa secara umum buku teks Kemendikbud Matematika kelas VII edisi revisi 2014 belum sepenuhnya sesuai dengan Kurikulum 2013. Karena itu, perlu ditinjau lebih lanjut untuk dilakukan perbaikan pada beberapa ketidaksesuaian yaitu pada cakupan materi, kesesuaian KD, kedalaman materi dan kesesuaian dengan tingkat kognitif siswa, penyajian materi, dan kesesuaian dengan Standar Penilaian.

\section{SIMPULAN}

Berdasarkan hasil analisis data yang diperoleh dalam penelitian ini, diperoleh beberapa kesimpulan buku teks matematika kelas VII edisi revisi tahun 2014 belum sepenuhnya sesuai dengan standar isi, standar proses dan standar penilaian. Tingkat kesesuaian dengan standar isi yakni: (1) kesesuaian cakupan materi dalam buku teks Kemendikbud Matematika kelas VII edisi revisi 2014 dengan cakupan materi dalam Kurikulum 2013 adalah sebesar 90,91\%; (2) kesesuaian KD dalam buku dengan KD pada Kurikulum 2013 adalah sebesar 95,45\%; (3) kesesuaian keluasan materi dalam buku dengan keluasan materi dalam Kurikulum 2013 adalah sebesar 90,91\%; (4) kesesuaian kedalaman materi dalam buku dengan kedalaman materi dalam Kurikulum 2013 adalah sebesar 90,91\%; dan (5) keakuratan materi dalam buku adalah sebesar $81,82 \%$. Sementara itu, kesesuaian materi dalam buku teks matematika kelas VII edisi revisi 2014 dengan Standar Proses pada Kurikulum 2013 dilihat dari segi format adalah sebesar 90,9\% dalam hal ini cara penyampaian materi dengan menggunakan pendekatan saintifik yang merupakan bagian dari Standar Proses sesuai dengan tuntutan dalam Kurikulum 2013.
Selanjutnya kesesuaian materi dalam buku teks Kemendikbud Matematika kelas VII edisi revisi 2014 dengan standar penilaian pada Kurikulum 2013 adalah sebesar 54,55\% yang menunjukkan bahwa buku teks kurang sesuai dengan tuntutan penilaian dalam Kurikulum 2013.

\section{DAFTAR PUSTAKA}

Agustina, D. A. (2015). Analisis buku teks tematik integratif berbasis scientific approach dan authentic assessment pada Kurikulum 2013 kelas V tema 1 bendabenda di lingkungan sekitar. Tesis, magister, tidak diterbitkan, Universitas Negeri Yogyakarta, Yogyakarta.

Anderson, L. W. \& Krathwohl, D.R. (2001). A Taxonomy for learning, teaching, and assessing: A revision of bloom's taxonomy of educational objectives (A Bridged Edition). Boston: Addison Wisley Longman, Inc.

Biggs, J.B. \& Collis, K.F. (1982). Evaluating the quality of learning: The solo taxonomy (structure of the observed learning outcome). London: Academic Press, Inc.

Gerde, H. K. \& Schachter, R. E. (2013). Using the scientific method to guide learning: An Integrated approach to early childhood curriculum. Early Childhood Educ J. 41, 315-323.

Kemendikbud. (2014a). Matematika: SMP/MTs kelas VII semester 1 (edisi revisi 2014). Jakarta: Puskurbuk.

Kemendikbud. (2014b). Matematika: SMP/MTs kelas VII semester 2 (edisi revisi 2014). Jakarta: Puskurbuk.

Krippendorff, K. (2004). Content analysis: An introduction to its methodology $\left(2^{\text {nd }} e d\right.$.). USA: Sage publications, Inc.

Macintyre, T. \& Hamilton, S. (2010). Mathematics learners and mathematics textbooks: A Question of identity? Whose curriculum? Whose mathematics? The Curriculum Journal, 21(1), 3-23.

Mendikbud. (2013a). Peraturan Menteri Pendidikan dan Kebudayaan Republik Indonesia nomor 65 tahun 2013 tentang standar proses.

Mendikbud. (2013b). Menteri Pendidikan dan Kebudayaan RI Nomor 66 tahun 2013 tentang standar penilaian pendidikan. 
Pythagoras, 12 (1), 2017 - 22

Apolonia Hendrice Ramda

Mendikbud. (2014a). Peraturan Menteri Pendidikan dan Kebudayaan RI Nomor 58 Tahun 2014, tentang kurikulum 2013 sekolah menengah pertama/madrasah tsanawiyah.

Mendikbud. (2014b). Peraturan Menteri Pendidikan dan Kebudayaan RI Nomor 103 Tahun 2014, tentang pembelajaran pada pendidikan dasar dan pendidikan menengah.

Mendikbud. (2014c). Peraturan Menteri Pendidikan dan Kebudayaan RI Nomor 104 Tahun 2014, tentang penilaian hasil belajar oleh pendidik pada pendidikan dasar dan pendidikan menengah

Mesa, V. \& Griffiths, B. (2012). Textbook mediation of teaching: An example from tertiary mathematics instructors. Education Study Mathematics, 79,85-107.

Miller, M. D., Linn, R. L. \& Gronlund, N. E. (2009). Measurement and assessment in teaching (10th ed.). Upper Saddle River: Pearson.

NCTM. (2000). Principles and standar for school mathematics. Reston: The national council of mathematics, Inc.

Neuendorf, K. A. (2002). The content analysis guidebook. London: Sage publications, Inc.

Novianto, A., \& Mustadi, A. (2015). Analisis buku teks muatan tematik integratif, scientific approach, dan authentic assessment sekolah dasar. JURNAL KEPENDIDIKAN, 45(1). Retrieved from http://journal.uny.ac.id/index.php/jk/ article/view/7181
Nitko, A. J. \& Brookhart, S. M. (2011). Educational assessment of students (6th ed). Boston: Pearson.

O'Keeffe, L. (2013). A framework for textbook analysis. International Review of Contemporary Learning Research, 2(1), $1-13$. https://doi.org/10.12785/irclr/020101

Presiden. Peraturan Pemerintah RI Nomor 32 Tahun 2013, tentang Standar Nasional Pendidikan.

Rusindrayanti, R., \& Santoso, R. (2015). Implementasi Pendekatan Saintifik Mapel Matematika Kelas VII Tahun Pelajaran 2013/2014 pada Kurikulum 2013 DIY. PYTHAGORAS: Jurnal Pendidikan Matematika, $\quad$ 10(1), 80-94. doi:http://dx.doi.org/10.21831/pg.v10i1.9 112

Shield, M. \& Dole, S. (2013). Assessing the potential of mathematics textbooks to promote deep learning. Education Study Mathematics, 82, 183-199.

Soeyono, Y. (2014). Pengembangan Bahan Ajar Matematika dengan Pendekatan Openended untuk Meningkatkan Kemampuan Berpikir Kritis dan Kreatif Siswa SMA. PYTHAGORAS: Jurnal Pendidikan Matematika, $\quad$ 9(2), 205-218. doi:http://dx.doi.org/10.21831/pg.v9i2.90 81

Weinberg, A. \& Wiesner E. (2011). Understanding mathematics textbooks through reader-oriented theory. Educ Stud Math, 76, 49-63. 